\title{
RURAL LIVELIHOODS TRANSITIONS: TOWARDS AN INTEGRATION OF THE SUSTAINABLE LIVELIHOODS APPROACH AND THE MULTI-LEVEL PERSPECTIVE
}

\begin{abstract}
Hamid EL BILALI, Centre for Development Research, University of Natural Resources and Life Sciences (BOKU), Borkowskigasse 5, 1190 Vienna, Austria; hamid.elbilali@boku.ac.at (corresponding author)

Michael HAUSER, Centre for Development Research, University of Natural Resources and Life Sciences (BOKU), Borkowskigasse 5, 1190 Vienna, Austria; michael.hauser@ boku.ac.at \& International Crops Research Institute for the Semi-Arid Tropics (ICRISAT), United Nations Avenue, Gigiri P.O. Box 39063, 00623 Nairobi, Kenya; M.Hauser@ cgiar.org

Sinisa BERJAN, Faculty of Agriculture, University of East Sarajevo, Vuka Karadzica 30, 71126 East Sarajevo, Bosnia and Herzegovina; sinisaberjan@yahoo.com

Otilija MISECKAITE, Institute of Water Resources Engineering, Water and Land Management Faculty, Aleksandras Stulginskis University, Studentu 11, Akademija, 53361 Kaunas, Lithuania; otilija.miseckaite@asu.1t

Lorenz PROBST, Centre for Development Research, University of Natural Resources and Life Sciences (BOKU), Borkowskigasse 5, 1190 Vienna, Austria; lorenz.probst@boku.ac.at

In rural areas, especially in low and middle-income countries, livelihoods have to diversify to include new on- and off-farm activities. However, sustainable livelihood concepts have so far not sufficiently accommodated transition dynamics. Mostly, rural livelihoods and sustainability transitions are addressed separately in the scientific literature. The aim of this review paper is to explore opportunities to integrate the Sustainable Livelihoods Approach (SLA) and the Multi-Level Perspective (MLP) on transitions. We provide an overview of the SLA and MLP. We then focus on the conceptual linkages between SLA and MLP, in particular regarding livelihood diversification strategies. Our review shows that the conceptual overlaps of the SLA and the MLP allow for a meaningful combination of both approaches to harness their respective strengths. Vulnerabilities from the SLA perspective (e.g. shocks, trends, changes) are considered at the landscape level in MLP. Policies, institutions, processes in SLA are part of 'regime' in the MLP heuristic. The livelihood diversification in SLA, e.g. the development of new on- and off-farm activities, can be described as niches in MLP. Some empirical work on agricultural transitions from the MLP perspective has adopted a territorial approach to take into consideration the pluri-activity of farms and the interactions between different subsystems (food, energy and tourism). This resonates well with the idea of livelihood diversification as a strategy in SLA. We conclude that integrating SLA and MLP will help to better understand livelihood diversification processes and we provide a preliminary proposal for a livelihood transition framework.
\end{abstract}

Keywords: Livelihood diversification, Multi-Level Perspective, Sustainable Livelihoods Framework, Sustainability transitions.

\section{INTRODUCTION}

Despite its declining contribution to the gross domestic product (GDP), agriculture continues to have an important influence on the rural economy (OECD, 2006; UNEP, 2010; FAO, 2017a). The agriculture sector provides livelihoods for $40 \%$ of the world's population (CGIAR, 2012). Nevertheless, as an economy grows the non-farm economy also grows in importance within the rural economy (Valdés et al., 2008). The rural non-farm economy has grown rapidly in middle and some low-income countries in last decades; as for the period 1990s-2000s, Reardon et al. (2007) estimate the contribution of non-farm earnings being about 50\% in Latin America and Asia and about 35\% in Africa. Widespread rural-urban migration will further reduce the number of people living in rural areas. The share of the world population living in rural areas decreased from $70 \%$ in 1950 to $46 \%$ in 2015, and is likely to reach 34\% in 2050 (UN-DESA, 2014). Yet, rural economies remain crucially important. A recent report by FAO (2017:v) concluded that "fulfilling the 2030 Agenda depends crucially on progress in rural areas, which is where most of the poor and hungry live". In other words, there will be no sustainable development without the development of rural areas.

Urbanisation is a driver of rural transformation; a process that is embedded in structural transformation and leads to increases in agricultural productivity as well as to the diversification of production patterns and livelihoods, by developing off-farm and non-farm employment (IFAD, 2016). Rural transformations in many countries are driven by agricultural productivity growth, leading to a shift of resources and people from agriculture towards industry and services (FAO, 2017). A vast literature confirms that in most rural areas, livelihoods diversification is the norm, rather than the exception (e.g. OECD, 2006; World Bank, 2007; Haggblade et al., 2007; IFAD, 2016; FAO, 2017). The literature also

Copyright (C) 2017 The Authors. Published by Aleksandras Stulginskis University. This is an open-access article distributed under the terms of the Creative Commons Attribution License (CC-BY 4.0), which permits unrestricted use, distribution, and reproduction in any medium, provided the original author and source are credited. 
suggests that rural households participating in non-farm activities have higher income (e.g. Davis et al., 2010; Möllers and Buchenrieder, 2011; Bezu et al., 2012; Davis et al., 2017; FAO, 2017) and that inclusive rural transformation requires the development of the non-farm economy (IFAD, 2016).

Many frameworks have been proposed to understand livelihood diversification at different levels (household, farm, territory / region). One of the most prominent frameworks is the Sustainable Livelihoods Framework (Scoones, 1998; DFID, 1999; Ellis, 2000). Furthermore, OECD (2009) provided a farm household income diversification framework. It differentiates between activities in terms of resources (factors of production: land, labour or capital), location (on-farm or off-farm) and output (agricultural or non-agricultural / non-farm). Many factors influence the diversification of farm households into non-farm activities, including government intervention. Providing the services needed to foster business in rural areas also helps creating an environment conducive to diversification (OECD, 2009; IFAD, 2010). However, the challenges of income diversification for agricultural holdings have a strong regional character and lie in the characteristics of the farm or farm household (DEFRA, 2007). The size and type of farm operations are important factors in determining engagement in livelihood diversification endeavours. In general, off-farm diversification activities are undertaken largely by smaller farmers, for whom they are more financially important. The location of the farm, especially distance to urban areas, also plays an important role in determining the extent of diversification activities (OECD, 2009; Nagler and Naudé, 2014).

Taking into consideration rural livelihoods diversification, many scholars dealing with sustainability transitions in agriculture - mainly using the Multi-Level Perspective (MLP) on transitions - highlighted that it is important to adopt a territorial approach that allows taking into consideration the interactions between niches linked to different sectors (e.g. food, energy and recreation). In general, analysing transitions in farming pose several conceptual challenges due, among others, to multi-functionality and pluri-activity of farms (Sutherland et al., 2014). Many rural development initiatives are the sites of novelties and niches development, but it is not clear under which conditions they induce a transition, which is the core issue in research on sustainability transitions (Darnhofer, 2015). In the framework of studies on rural development, the term 'transition' has been used to indicate a farm level reconfiguration and diversification of incomegenerating activities (Wilson, 2007; Milone, 2009; Lamine and Bellon, 2009) but often without paying attention to changes in dominant practices at larger scales (cf. regional, national). The work on endogenous rural development (e.g. van der Ploeg and Marsden, 2008) generally does not refer to any transition conceptual framework. Likewise, work on livelihood diversification even in transition contexts (e.g. Huber et al., 2014) or referring explicitly to rural livelihood change (e.g. Bhandari, 2013; Mushongah and Scoones, 2012; Liu and Liu, 2016), overlooks transition - and sustainability transitions (Markard et al., 2012; Lachman, 2013) - literature.

Therefore, this review paper explores the integration of the Sustainable Livelihoods Framework and the MultiLevel Perspective to better understand dynamics and processes of rural livelihoods diversification.

\section{SUSTAINABLE LIVELIHOODS FRAMEWORK}

Besides economic activities, livelihoods include the political and cultural context of rural household sustenance as well as natural, human and social resources of households. According to (DFID, 1999) "A livelihood comprises the capabilities, assets and activities required for a means of living. A livelihood is sustainable when it can cope with and recover from stresses and shocks and maintain or enhance its capabilities and assets both now and in the future, while not undermining the natural resource base."
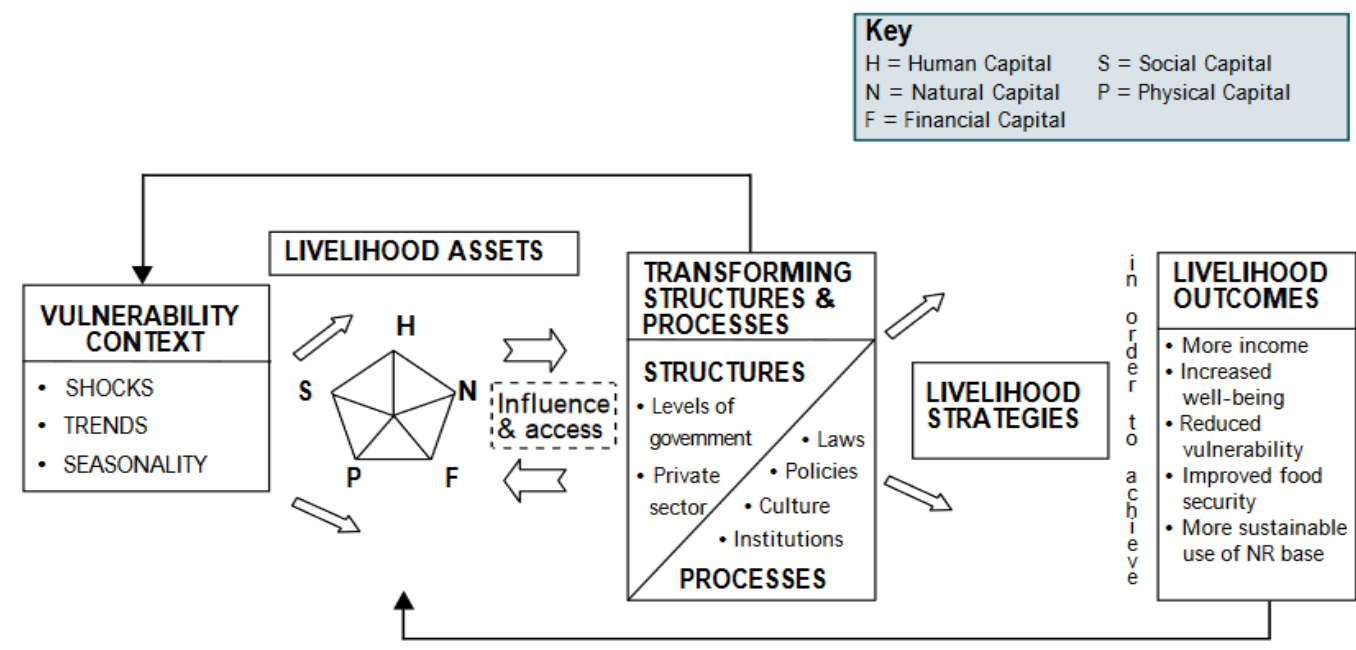

Source: DFID, 1999:1.

Figure 1. Sustainable Livelihoods Framework.

The Sustainable Livelihoods Framework (Scoones, 1998; DFID, 1999; Ellis, 2000; GLOPP, 2008) highlights the multiple dimensions of livelihoods and the inherently complex systems of human-environmental interactions. According to DFID (1999), the Sustainable Livelihoods Framework (SLF) summarises the main components of and influences on livelihoods. It presents the main factors that affect people's livelihoods and relationships between them. The main 
components of the SLF are vulnerability context, livelihoods assets, transforming structures and processes (cf. policies, institutions and processes - PIPs - in other framework versions), livelihoods strategies and livelihoods outcomes (Figure 1). Livelihoods are shaped by different factors and forces that are themselves constantly shifting. There are also important feedback loops between the SLF components (e.g. PIPs - vulnerability context; livelihood outcomes - livelihood assets). Scoones (1998) distinguishes between different livelihood strategies: agricultural intensification (increasing productivity per area unit), extensification (putting additional land under cultivation), diversification (development of off-farm activities), and migration. Many studies have examined household livelihood transition from farming to non-farm activities (Barrett et al., 2001; Reardon et al., 2006; Bhandari, 2013; Davis et al., 2017) also called 'farm exit' (Bhandari, 2013). Natural (natural resources such as land, flora and fauna, water), human (skills, knowledge, health), financial (savings, ownership of livestock, remittances), physical (roads, infrastructure, equipment, tools), and social (networks and connections, membership of groups, relationships of trust and reciprocity) capitals/assets (DFID, 1999) affect the capacity of rural households to develop successful livelihood transition and diversification strategies (Bhandari, 2013).

\section{MULTI-LEVEL PERSPECTIVE (MLP) ON TRANSITIONS}

MLP is a heuristic to analyse the development trajectory of socio- technical transformations. According to the MLP (Rip and Kemp, 1998; Geels, 2002; Smith et al., 2005; Geels, 2010; Schot and Geels, 2008; Smith et al., 2010) transitions come about through interacting processes within and between three analytical levels: niches (micro level; locus of radical innovations); socio-technical regimes (meso level; locus of established practices and associated rules); and an exogenous socio-technical landscape (macro level).

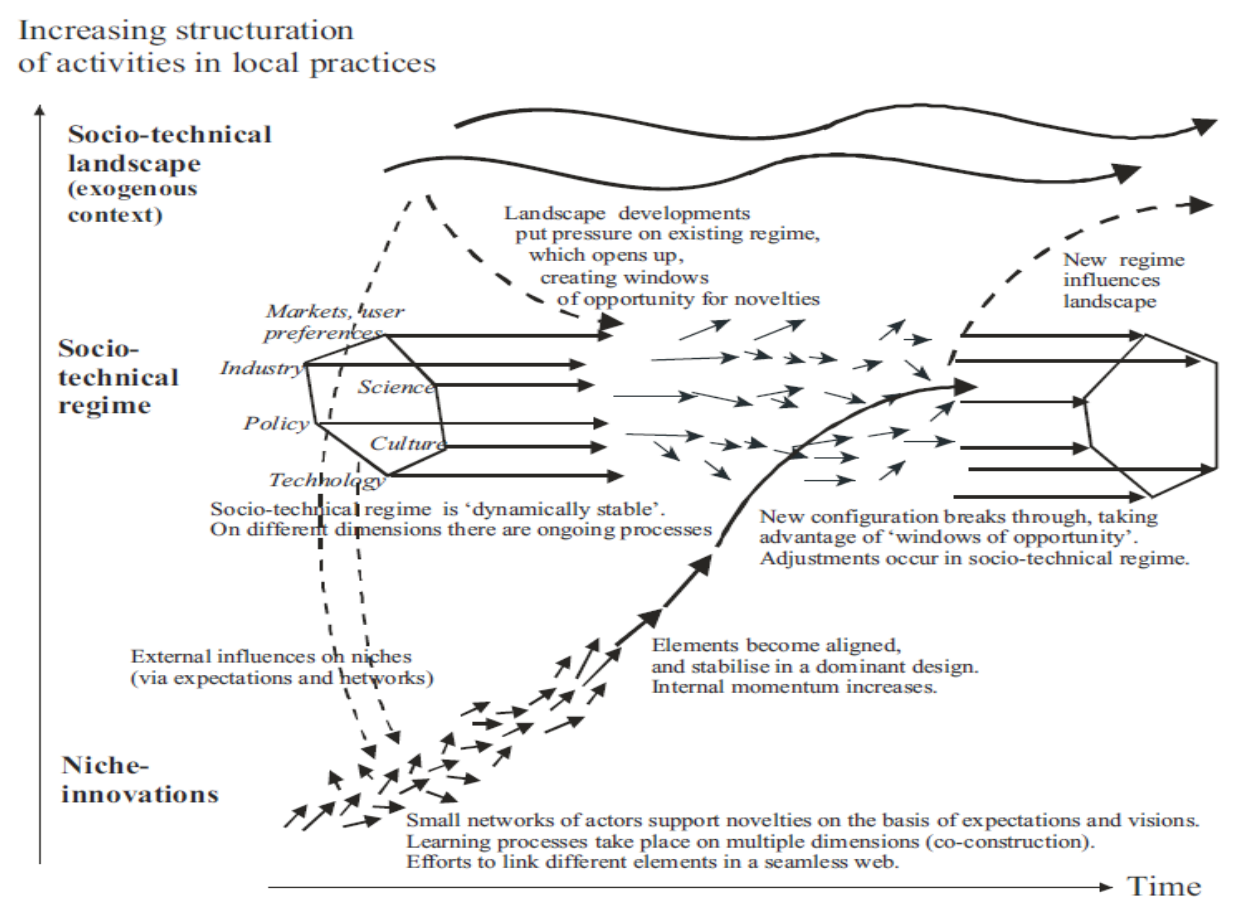

Source: Adapted by Geels (2011) from Geels (2002:1263).

Figure 2. Transition in the Multi-Level Perspective (MLP).

Niches or novelties are vital for sustainability transitions (Hinrichs, 2014; Lachman, 2013). The aim of a niche is to bring about change in socio-technical systems (e.g. agro-food system) by focusing on new technologies and practices, actor groups' configurations, networks, policies, etc. (Darnhofer, 2015). The elements of a regime include the network of actors and social groups involved in a socio-technical system, the set of formal and informal rules that guide the activities of these actors, and material and technical elements in the system (Geels, 2004). Sterrenberg et al. (2013) distinguish between regulative, normative and cognitive rules and institutions as components of a socio-technical regime. These rules and institutions - that determine, in general, resistance to change or even a lock-in of the system - may relate to markets and consumer preferences, policy, science and education, culture, and practices and technologies (Geels, 2002; Geels, 2011). The landscape encompasses external trends, changes and exogenous factors that create pressure or opportunities in socio-technical systems (Geels, 2002; Geels and Schot, 2007). For instance, in the case of agro-food systems these external trends may regard demography, economy, trade, climate change, politics, shocks and crises (Darnhofer, 2014). In MLP, transitions are defined as shifts from one regime to another regime and they result from the interaction between processes at niche-regime-landscape levels (Figure 2): niche-innovations build up internal momentum; changes at the landscape level create destabilising pressure on the regime; and regime destabilisation creates windows of opportunity for radical niche innovations (Markard and Truffer, 2008; Geels, 2011). MLP emphasises that processes at niche, regime and landscape levels should be aligned for a transition to be successful (Geels, 2011). MLP scholars have identified the following transition pathways or patterns (Geels and Schot, 2007): reproduction process (stable regime in absence of 
landscape pressure); transformation pathway; de-alignment and re-alignment pathway; technological substitution; and reconfiguration. However, transition pathways can start in following one path but later shift to another.

\section{PROPOSAL FOR A RURAL LIVELIHOOD TRANSITION FRAMEWORK}

Scrutiny of the MLP and the SLF shows that there are many similarities between them. In fact, even if literature on MLP does not make any reference to SLF (which may be due to the fact that the two frameworks were developed in different periods and contexts), the key concepts of MLP (cf. niche, regime, landscape) can be easily integrated - and are implicitly present - in the SLF especially when it comes to livelihood diversification. Niches or novelties can be used to refer to livelihood diversification in terms of the development of new activities at farm level or off-farm. Surprisingly, also the elements of landscape in MLP are quite similar to those of the vulnerability box in SLF (cf. trends, shocks, changes). Both of them refer to external factors that cannot be controlled by niche actors (e.g. a household that tries to diversify its livelihoods) but have an impact on the success of transition or diversification endeavours. The regime in the MLP refers to the dominant/incumbent socio-technical system, whose interaction with the niche determines the impact of transition initiatives. Similarly, one can say that it is interaction with the dominant livelihood system (i.e. agriculture) that determines the possibility to develop livelihood diversification strategies and affects their success. In fact, established policies, institutions (both hard and soft ones as rules and behaviours) and processes in agriculture - as well as in other socio-technical systems such as energy and tourism - play a crucial role in delimiting the portfolio of diversification activities in each rural context and for each rural household. According to DFID (1999), the SLF is dynamic (cf. transition) and links micro-macro levels (cf. multilevel) and this resonates well with the logic of MLP.

Given the above-described similarities and complementarities between the two frameworks, we explore hereafter their integration by proposing a rural livelihood transition framework (Figure 3).

The proposed framework highlights interactions between different factors and elements that determine the possibility and success of rural livelihood diversification endeavours as well as their potential for scaling up in each rural area. Although the framework is represented in a linear diagram that does not mean that the starting point is landscape and context and the ending one is rural livelihood outcomes. There are at least two different ways to apprehend the notion of transition in this framework; the first is that the concept of livelihood diversification implies the idea of shift or transformation in the livelihood system, while the second, is that the interactions and interfaces between the components of the system are constantly shifting and that determine also changes in rural livelihoods over time.

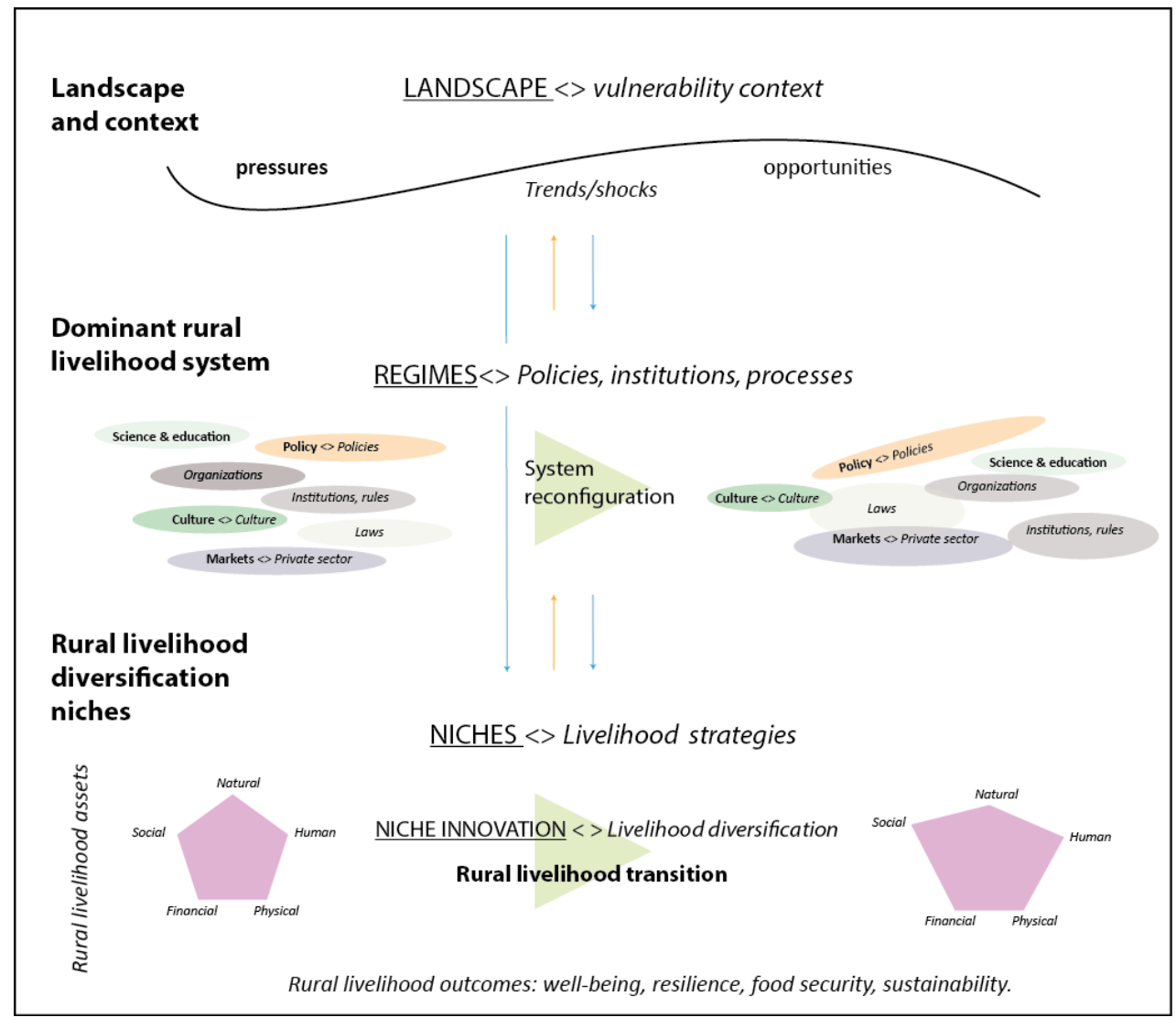

Legend:

Bold: New elements of the rural livelihood transition framework;

CAPITALS AND UNDERLINED: Elements of the MLP;

Italics: Elements of the SLF.

Figure 3. Proposed rural livelihoods transition framework. 
As per the MLP, the proposed framework assumes that a rural livelihood transition, so development of niches or diversification, comes about through complex and multi-level interactions between the different components of the livelihood system. It also admits that there should be an alignment between landscape and context, dominant rural livelihood system and rural livelihood diversification niche to have such a transition. Landscape and context - that cannot be changed by rural households - can create opportunities for rural niches but also exert pressure on the dominant rural livelihood system (cf. agriculture) to change. For instance, climate change is pushing many rural people to exit agriculture and to diversify their livelihoods. Landscape and context as well as dominant rural livelihood system have an impact on rural livelihood assets. These two components determine also the range of diversification strategies (cf. rural livelihood diversification niches) that can be pursued in each rural context. Although many niches can be present in a rural area, they do not become mainstream livelihood strategy as far as the dominant livelihood system (cf. agriculture) is strong and viable. Moreover, the success of a livelihood niche (e.g. rural tourism) depends also on its viability, opportunities created by landscape and context as well as attitude of the dominant rural livelihood system and its actors. The engagement, or not, of a rural household in livelihood diversification niches determine its livelihood outcomes, and, as per the SLF, these have an impact on livelihood assets.

It should be pointed out that in real-life context it is often not a question of clear-cut and distinct transition from a livelihood strategy to another; rather, it is a long-term dynamic process in which rural households combine activities and livelihoods strategies to meet their various needs. This may imply inclusion of a new niche activity in their livelihoods portfolio and the new activity might become over time the most important one in terms of income generation.

Although the proposed framework addresses principally the core notion of transition, we think that it can be used also in sustainability transitions studies. In fact, assessment of the sustainability of a livelihood transition (cf. sustainability transitions) can be performed by comparing the current livelihood assets state to the previous one (cf. longitudinal analysis) or by comparing it to that of rural households in the same territory (cf. in the same landscape and context) that are not engaged in the diversification endeavour (cf. horizontal analysis).

An obvious advantage of this proposed framework is the possibility to use the rich and multifaceted literature on transition in general and sustainability transitions in particular in the analysis of rural livelihoods diversification pathways. Although the proposed framework is more adapted to understand livelihood transition dynamics at household level, as in the case of the SLF, its integration of the MLP approach and setting makes it appropriate to analyse livelihood transitions also at larger rural scales (cf. community, local, regional).

\section{CONCLUSIONS}

During socio-economic transitions in rural areas, livelihoods integrate new off-farm and on-farm activities. This diversification affects in turn the rural economy, which underlines the linkages between diversification at household level (that is better understood using the Sustainable Livelihoods Framework) and transitions in rural economies at local and regional scales (that are better analysed using the Multi-Level Perspective). To our best knowledge, no heuristic framework has been proposed that allows analysing processes across these multiple levels of transition. We therefore suggest an integration of the MLP and the SLF and argue that this integration will help to better understand rural livelihood transition and diversification processes at household and territorial level. Based on that, we propose a livelihood transition framework for further development, testing and validation in different rural settings and contexts particularly in the Global South. A further step in the process of bridging the gap between approaches of sustainable livelihoods and sustainability transitions can be to test how other concepts, such as Transition Management and Strategic Niche Management, could be integrated.

\section{REFERENCES}

1. Barrett, C., Reardon, T., Webb, P. 2001. Non-farm income diversification and household livelihood strategies in rural Africa: concepts, issues, and policy implications. Food Policy, Vol. 26 (4), pp.315-331. https://doi.org/10.1016/S0306-9192(01)00014-8

2. Bezu, S., Barrett, C., Holden, S. 2012. Does nonfarm economy offer pathways for upward mobility? World Development, Vol. 40 (8), pp.1634-1646. https://doi.org/10.1016/j.worlddev.2012.04.019

3. Bhandari P. B. 2013. Rural livelihood change? Household capital, community resources and livelihood transition. Journal of Rural Studies, Vol. 32, pp.126-136. https://doi.org/10.1016/j.jrurstud.2013.05.001

4. Carney, D. 1998. Sustainable rural livelihoods: What contribution can we make? Department for International Development (DFID), London.

5. CGIAR 2012. Agriculture and Rural Development Day 2012: Lessons in Sustainable Landscapes and Livelihoods. Available at http://www.cgiar.org/press-releases/agriculture-and-rural-development-day-2012-lessons-in-sustainable-landscapes-andlivelihoods (Accessed on 29/07/2016).

6. Darnhofer, I. 2014. Conceptual Framework. Deliverable of FarmPath project "Farming Transitions: Pathways Towards Regional Sustainability of Agriculture in Europe". Available https://www.wiso.boku.ac.at/fileadmin/data/H03000/H73000/H73300/Ika/2014_FarmPath_ConceptualFramework.pdf (Accessed on 10/03/2017).

7. Darnhofer, I. 2015. Socio-technical transitions in farming: key concepts. In: Sutherland, L.A., Darnhofer, I., Wilson, G., Zagata, L. eds. Transition pathways towards sustainability in agriculture. Case studies from Europe. Wallingford: CABI, pp. 17-31. https://doi.org/10.1079/9781780642192.0017 
8. Davis, B., Di Giuseppe, S., Zezza, A. 2017. Are African households (not) leaving agriculture? Patterns of households' income sources in rural Sub-Saharan Africa. Food Policy, Vol. 67, pp.153-174. https://doi.org/10.1016/j.foodpol.2016.09.018

9. Davis, B., Winters, P., Carletto, G., Covarrubias, K., Quiñones, E.J., Zezza, A., Stamoulis, K., Azzarri, C., Di Giuseppe, S. 2010. A cross-country comparison of rural income generating activities. World Development, Vol. 38(1), pp.48-63. https://doi.org/10.1016/j.worlddev.2009.01.003

10. DEFRA 2007. Barriers to farm diversification. Report of the Joint Industry-Government Working Group. Department for Environment, Food and Rural Affairs (DEFRA), London, UK.

11. DFID 1999. Sustainable Livelihoods Guidance Sheets. Department for International Development (DFID), UK. Available at http://www.eldis.org/vfile/upload/1/document/0901/section2.pdf (accessed on 10/10/2017).

12. Ellis, F. 2000. Rural livelihoods and diversity in developing countries. Oxford University Press, Oxford, UK.

13. FAO 2017. The State of Food and Agriculture - Leveraging food systems for inclusive rural transformation. FAO, Rome. Available at www.fao.org/3/a-i7658e.pdf (Accessed on 15/10/2017).

14. FAO 2017a. The future of food and agriculture - trends and challenges. Rome. Available at www.fao.org/3/a-i6583e.pdf (Accessed on 18/10/2017).

15. Geels, F.W., Schot, J.W. 2007. Typology of sociotechnical transition pathways. Research Policy, Vol. 36, pp.399-417. https://doi.org/10.1016/j.respol.2007.01.003

16. Geels, F.W. 2002. Technological transitions as evolutionary reconfiguration processes: a multi-level perspective and a case-study. Res. Policy, Vool. 31, pp.1257-1274. https://doi.org/10.1016/S0048-7333(02)00062-8

17. Geels, F.W. 2004. From sectoral systems of innovation to socio-technical systems. Insights about dynamics and change from sociology and institutional theory. Research Policy, Vol. 33, pp.897-920. https://doi.org/10.1016/j.respol.2004.01.015

18. Geels, F.W. 2010. Ontologies, socio-technical transitions (to sustainability), and the multi-level perspective. Research Policy, Vol. 39, pp.495-510. https://doi.org/10.1016/j.respol.2010.01.022

19. Geels, F.W. 2011. The multi-level perspective on sustainability transitions: Responses to seven criticisms. Environ. Innov. Soc. Transitions, No.1, pp.24-40. https://doi.org/10.1016/j.eist.2011.02.002

20. GLOPP 2008. DFID's Sustainable Livelihoods Approach and its Framework. Globalisation and Livelihood Options of People living in Poverty (GLOPP). Available at www.glopp.ch/B7/en/multimedia/B7_1_pdf2.pdf (Accessed on 20/10/2017).

21. Haggblade, S., Hazell, P., Reardon, T. 2007. Transforming the rural non-farm economy. International Food Policy Research Institute (IFPRI) and Johns Hopkins University Press, Washington D.C, USA.

22. Hinrichs, C.C. 2014. Transitions to sustainability: a change in thinking about food systems change? Agric Hum Values, Vol. 31, pp.143-155. https://doi.org/10.1007/s10460-014-9479-5

23. Huber, F. K., Yang, Y., Weckerle, C. S., Seeland, K. 2014. Diversification of Livelihoods in a Society in Transition: A Case Study of Tibetan Communities in Southwest China. Society and Natural Resources, Vol. 27, pp.706-723. https://doi.org/10.1080/08941920.2014.901465

24. IFAD 2010. Rural poverty report 2011 - New realities, new challenges: new opportunities for tomorrow's generation. International Fund for Agricultural Development (IFAD), Rome, Italy.

25. IFAD 2016. Rural Development Report 2016. Fostering inclusive rural transformation. IFAD (International Fund for Agricultural Development), Rome.

26. Lachman, D.A. 2013. A survey and review of approaches to study transitions. Energy Policy, Vol. 58, pp.269-276. https://doi.org/10.1016/j.enpol.2013.03.013

27. Lamine, C., Bellon, S. eds. 2009. Transitions vers l'agriculture biologique [Transitions towards organic farming], Editions Quæ, Versailles.

28. Liu, Z. and Liu, L. 2016. Characteristics and driving factors of rural livelihood transition in the east coastal region of China: A case study of suburban Shanghai. Journal of Rural Studies, Vol. 43, pp. 145-158. https://doi.org/10.1016/j.jrurstud.2015.12.008

29. Markard, J. and Truffer, B. 2008. Technological innovation systems and the multi-level perspective: towards an integrated framework. Research Policy, Vol. 37 (4), pp.596-615. https://doi.org/10.1016/j.respol.2008.01.004

30. Markard, J., Raven, R., Truffer, B. 2012. Sustainability transitions: an emerging field of research and its prospects. Research Policy, Vol. 41, pp. 955-967. https://doi.org/10.1016/j.respol.2012.02.013

31. Milone, P. 2009. Agriculture in transition. A neo-institutional analysis, Van Gorcum, Assen (theNetherlands).

32. Möllers, J., Buchenrieder, G. 2011. Effects of rural non-farm employment on household welfare and income distribution of small farms in Croatia. Quarterly Journal of International Agriculture, Vol. 50(3), pp.217-235.

33. Mushongah, J., Scoones, I. 2012. Livelihood Change in Rural Zimbabwe over 20 Years. Journal of Development Studies 48(9), pp.1241-1257. https://doi.org/10.1080/00220388.2012.671474

34. Nagler, P., Naudé, W. 2014. Non-Farm Enterprises in Rural Africa - New Empirical Evidence. Policy Research Working Paper 7066. The World Bank, Washington DC.

35. OECD 2006. The new rural paradigm: policies and governance, OECD Rural Policy Reviews, Organisation for Economic Cooperation and Development (OECD), Paris.

36. OECD 2009. The role of agriculture and farm household diversification in the rural economy: evidence and initial policy implications, OECD, Paris.

37. Reardon, T., Berdegue, J., Barrett, C., Stamoulis, K. 2006. Household Income Diversification into Rural Non-Farm Activities, Johns Hopkins University Press, Baltimore.

38. Reardon, T., Stamoulis, K., Pingali, P. 2007. Rural nonfarm employment in developing countries in an era of globalization. 
Agricultural Economics, Vol. 37, pp.173-183. https://doi.org/10.1111/j.1574-0862.2007.00243.x

39. Rip, A., Kemp, R. 1998. Technological change. In: Rayner, S., Malone, E.L. (eds.), Human Choice and Climate Change Resources and Technology. Battelle Press, Columbus, pp. 327-399.

40. Schot, J., Geels, F.W. 2008. Strategic niche management and strategic innovation journeys: theory, findings, research agenda and policy. Technology Analysis \& Strategic Management, Vol. 20, pp.537-554. https://doi.org/10.1080/09537320802292651

41. Scoones, I. 1998. Sustainable rural livelihoods: A framework for analysis. IDS Working Paper 72. Institute of Development Studies (IDS), $\quad$ Brighton, $\quad$ UK. http://opendocs.ids.ac.uk/opendocs/bitstream/handle/123456789/3390/Wp72.pdf?sequence=1 (Accessed on 10/03/2016).

42. Smith, A., Stirling, A., Berkhout, F. 2005. The governance of sustainable socio-technical transitions. Research Policy, Vol. 34, pp.1491-1510. https://doi.org/10.1016/j.respol.2005.07.005

43. Smith, A., Voß, J.P., Grin, J. 2010. Innovation studies and sustainability transitions: The allure of the multi-level perspective and its challenges. Research Policy, Vol. 39, pp.435-448. http://dx.doi.org/10.1016/j.respol.2010.01.023

44. Sterrenberg, L., Andringa, J., Loorbach, D., Raven, R., Wieczorek, A. J. 2013. Low-carbon transition through system innovation Theoretical notions and application. Pioneers into Practice Mentoring Programme 2013. Available at http://www.transitiepraktijk.nl/files/Low-carbon transition through system innovation 2013 reader final.pdf (Accessed on 15/01/2017).

45. Sutherland, L., Darnhofer, I., Wilson, G., Zagata, L. 2014. Transition Pathways towards Sustainability in Agriculture: Case Studies from Europe, CABI Publishing, Wallingford.

46. UN-DESA 2014. World Urbanization Prospects: the 2014 revision. Highlights. ST/ESA/SER.A/352, UN Department of Economic and Social Affairs (UN-DESA), Population Division, New York. Available at https://esa.un.org/unpd/wup/Publications/Files/WUP2014-Highlights.pdf (Accessed on 22/09/2017).

47. UNEP 2010. Green Economy Report: A Preview, United Nations Environment Programme (UNEP), Division of Technology, Industry and Economics, Châtelaine (Switzerland).

48. Valdés, A., Foster, W., Anríquez, G., Azzarri, C., Covarrubias, K., Davis, B., Di Giuseppe, S., Essam, T., Hertz, T., de la O, A.P., Quiñones, E., Stamoulis, K., Winters, P., Zezza, A. 2008. A profile of the rural poor. Background paper for the IFAD (International Fund for Agricultural Development) Rural poverty report 2011. Available at http://www.ifad.org/rpr2011/background/2.pdf (Accessed on 25/07/2012).

49. Van der Ploeg, J.D., Marsden, T. eds. 2008. Unfolding webs. The dynamics of regional rural development. Van Gorcum, Assen (the Netherlands).

50. Wilson, G.A. 2007. Multifunctional agriculture: A transition theory perspective, CABI, Wallingford. https://doi.org/10.1079/9781845932565.0000

51. World Bank 2007. World Development Report 2008 - Agriculture for development. Washington, DC. 